\title{
Renewable energy consumption and economic growth in Nigeria: any causal relationship?
}

\author{
Ekone Francis Azeakpono \\ Dept. of Economics and Actuarial Sciences \\ Crescent University, Abeokuta, Nigeria \\ Amaghionyeodiwe Lloyd \\ Department of Business and Economics \\ York College, City University of New York, USA
}

\section{Keywords}

Renewable Energy Consumption, Economic Growth, Causality, Nigeria

\begin{abstract}
This study examined the effect of renewable energy consumption on economic growth in Nigeria for the period 1990 to 2016. It further investigated the direction of causality between renewable energy consumption and economic growth in Nigeria. This was with a view to providing information on the relationship between renewable energy consumption and economic growth in Nigeria within the period of the study. Data collected was analysed using both descriptive analysis and econometric technique, which included unit root, correlation, co-integration, regression, and granger causality tests. The result showed that although renewable energy consumption and economic growth increased between 1990 and 2016 in Nigeria, renewable energy consumption had no significant positive impact on economic growth in Nigeria. Furthermore, there was no causality between renewable energy consumption and economic growth in Nigeria during the period of study. The study concluded that renewable energy consumption exerted an insignificant negative impact on economic growth in Nigeria. We recommend that investing in renewable energy should be encouraged and enhanced as this may be a way to reduce domestic fossil fuel consumption or to meet increasing energy demand without an increase of domestic fuel consumption to increase fuel exports and thus for higher revenues.
\end{abstract}

\section{Introduction}

Modern energy services, including renewable energy, have been a prerequisite to sustained development in every advanced economy. According to United Nations Environment Program (UNEP) (2015), renewable energy defined as any energy generated from natural processes including hydropower, geothermal, solar, tides, wind, biomass, and biofuels, made up $53.6 \%$ of the total gigawatt capacity of all energy technologies installed in 2015. This excludes large hydroelectric projects. According to (International Energy Agency (IEA) (2015b), renewable energy technologies were becoming much more prevalent in both developed and developing economies as they became cheaper, more reliable, and readily available. During 2015, and for the first time ever, developing economies invested more money into renewable than developed economies (UNEP, 2015). Renewable energy technologies had more benefits to developing countries than merely being environmentally friendly. They also could provide protection against future price increases in conventional fuels by diversifying the energy portfolio, aid in the balancing of both budget and trade deficits and created new local economic opportunities which supported poverty reduction and promoted economic growth (Worldwatch, 2005; REN21, 2015).

Given the importance of renewable energy in promoting economic growth, the empirical literature studying the relationship between renewable energy and economic growth has expanded considerably in the last decade. For instance, Khobai (2017) investigates the causal relationship between renewable energy consumption and economic growth in South Africa. It incorporates carbon dioxide emissions, capital formation and trade openness as additional variables to form a multivariate framework. His study determined the direction of causality between the variables using the Vector Error Correction Model (VECM). The results indicated the existence of a unidirectional causality flowing from renewable energy consumption to economic growth in the long run while the short run results suggested a unidirectional 
causality flowing from economic growth to renewable energy consumption. Amri (2017) examined the relationship between economic growth and energy consumption under two categories- renewable and non-renewable energy consumption. Using the ARDL model, he found that in both the short and long run relationship, there exist a bidirectional causality between non-renewable energy consumption and economic growth while a unidirectional causality from renewable energy consumption to economic growth exist in the long run. Halkos and Tzemes (2014) investigated the link between electricity consumption from renewable sources and economic growth for 36 countries covering the period between 1990 and 2011. They analyzed the entire sample of countries and then grouped the countries into subsamples. The results for the entire sample of countries established that the relationship increases only up to a certain level of economic growth. A highly non-linear relationship was realized for emerging and developing countries while for developed countries, an increasing non-linear relationship was observed.

Energy is an imperative enabler that affects many aspects of economic and human development. Thus, economic growth and development may be constrained without adequate energy capacity and access to affordable modern energy services. While modern energy services have been a prerequisite to sustained development in every advanced economy, energy access was often a prevalent problem in developing countries in general and specifically in Nigeria, as evidenced by the fact that over two-thirds of Africans lack access to electricity (IEA, 2015a). Encouragingly, Nigeria has huge renewable resources, which remained untapped including solar, hydroelectric, wind in coastal areas and geothermal in the northern region. In addition, past studies have been inconclusive as to what type of relationship exists between renewable energy and economic growth and there are few independent analyses of the Nigerian case as regard to growth. As such, this study sets out to answer the following the following research questions: What is the relationship between renewable energy consumption and economic growth in Nigeria? Is there a causal relationship between renewable energy consumption and economic growth in Nigeria?

Thus, given the role of renewable energy in enhancing sustainable development, and to provide answers to the above research questions, this study empirically investigated the relationship between renewable energy consumption and economic growth in Nigeria. This was done using secondary data covering the period 1990 to 2016 while the estimation included both qualitative (descriptive) analysis and quantitative analysis involving unit root test, cointegration test, regression analysis and granger causality test.

\section{Literature Review}

Several empirical studies have investigated the relationship between economic growth and renewable energy consumption or renewable electricity consumption either within country context or panel data studies.

Among these studies are Sari, Ewing, and Soytas, (2008). Using a sample period that covers 2001:1 to 2005:6, they investigated the relationship between disaggregate energy consumption and industrial production in the United States using the autoregressive distributed lag (ARDL) approach. They focused attention on the following energy consumption variables: coal, fossil fuels, conventional hydroelectric power, solar energy, wind energy, natural gas, wood, and waste. Their results indicate that real output and employment are long run forcing variables for nearly all measures of disaggregate energy consumption. Odularu and Okonkwo (2009) investigate the relationship between energy consumption and the Nigerian economy from the period of 1970 to 2005. The energy sources used to test for this relationship were crude oil, electricity, and coal. By applying the cointegration technique, the results derived infer that there exists a positive relationship between current period energy consumption and economic growth. With the exception of coal, which was positive, a negative relationship was noted for lagged values of energy consumption and economic growth. The implication of the study is that increased energy consumption is a strong determinant of economic growth having an implicit effect in lagged periods and both an implicit and explicit effect on the present period in Nigeria.

Yildirim, Sarac and Aslan, (2012) study was on energy consumption and economic growth in the USA: Evidence from renewable energy. Their study focuses on the first issue by applying TodaYamamoto procedure and bootstrap-corrected causality test for the US since empirical literature criticizes the Toda-Yamamoto test, which bases on asymptotic distribution. The models consist of real GDP, 
employment, investment, and kinds of renewable energy consumption. Only one causal relationship was found from biomass-waste-derived energy consumption to real GDP. No causal relationship was found between real GDP and all of the other renewable energy kinds-total renewable energy consumption, geothermal energy consumption, hydroelectric energy consumption, biomass energy consumption and biomass-wood-derived energy consumption. That is using of energy from waste cause not only solving the dumping problems but also it contributes to real GDP. For policy purpose, the results of this study suggest that countries should concentrate on energy producing from waste as an alternative energy resource.

Pao and Fu (2013) examined the relationship between renewable energy, non-renewable energy, and economic growth in Brazil. Their study employed data from 1980 to 2010 to explore the causal relationships between the real GDP and four types of energy consumption: non-hydroelectric renewable energy consumption (NHREC), total renewable energy consumption (TREC), non-renewable energy consumption (NREC), and the total primary energy consumption (TEC). They found a long-run equilibrium among Brazil's real GDP, labour, capital, and each of the four types of consumption. Also, the influence of NHREC/TREC on real output was positive and significant, while the impacts by NREC/TEC are insignificant. The results from the vector error correction models reveal a unidirectional causality from NHREC to economic growth, a bidirectional causality between economic growth and TREC, and a unidirectional causality from economic growth to NREC or TEC without feedback in the long run. They concluded that their findings suggest that Brazil is an energy-independent economy and that economic growth is crucial in providing the necessary resources for sustainable development. Ogundipe and Apata (2013) examined the relationship between electricity consumption and economic growth in Nigeria using the Johansen and Juselius Co-integration technique based on the Cobb-Douglas growth model covering the period 1980 to 2008. The study also conducted the Vector Error Correction Modeling and the Pair wise Granger Causality test in order to empirically ascertain the direction of causality between electricity consumption and economic growth. The study found the existence of a unique co-integrating relationship among the variables in the model with the indicator of electricity consumption have a significantly impact on growth. Also, the study shows an evidence of bi-directional causal relationship between electricity consumption and economic growth.

Leitao (2014) applied time series (OLS, GMM, VECM and Granger causality) to examine the relationship between economic growth, carbon dioxide emissions, globalization and renewable energy in Portugal, and he concluded that renewable energy, carbon dioxide emissions, globalization are correlated positively with economic growth, and causality test indicated conservation hypothesis between renewable energy and economic growth. Lin (2014) concluded that there is bidirectional long-term causality between economic growth and renewable energy consumption in China by applying Granger causality test. Apergis and Danuletiu (2014) using the Canning and Pedroni (2008) long-run causality test examined the relationship between economic growth and renewable energy consumption for 80 countries and concluded bidirectional causality between renewable energy consumption and economic growth in the long-run. Kazar and Kazar(2014) investigated the relationship between development and renewable electricity net generation values for 154countries with panel analysis and found the presence of bidirectional causality in the short-run, and that the causal relationship differs both in short run and long run depending on human development level.

Omri et al. (2015) using dynamic simultaneous-equation panel data models for 17 developed and developing countries examined the relationship between nuclear consumption and renewable energy consumption and economic growth, and concluded mixed results for different countries and unidirectional causality running from economic growth to renewable energy consumption for the global panel. Jebli and Youssef (2015) did their study on Economic growth, combustible renewables and waste consumption, and $\mathrm{CO} 2$ emissions in North Africa. They used panel cointegration techniques and Granger causality tests to examine the dynamic causal link between per capita real gross domestic product (GDP), combustible renewables and waste (CRW) consumption, and $\mathrm{CO} 2$ emissions for a panel of five North African countries during the period 1971 to 2008. Their Granger causality test results suggest short- and long-run unidirectional causalities running from $\mathrm{CO} 2$ emissions and CRW consumption to real GDP and a short-run unidirectional causality running from CRW to $\mathrm{CO} 2$ emissions. The results from panel longrun 
fully modified ordinary least squares (FMOLS) and dynamic ordinary least squares (DOLS) estimates show that CO2 emissions and CRW consumption have a positive and statistically significant impact on GDP. They recommended that these countries should use more CRW. This increases their output, reduces their energy dependency on fossil energy, and may decrease their CO2 emissions. Aminu and Aminu (2015) set out to re-examine the causal relationship between energy consumption and economic growth using Nigeria's data from 1980 to 2011 in a multivariate framework by including labor and capital in the causality analysis. Applying Granger causality test, impulse response and variance decomposition analysis, their results reported absence of causality and that of variance decomposition found that capital and labor are more important in affecting output growth compared to energy consumption.

Tamba, Nsouandélé and Lélé (2017)'s study was on Gasoline consumption and economic growth in Cameroon. They analyzed the gasoline sector and examined the causal relationship between gasoline consumption and economic growth in Cameroon using annual data for the period 1975 to 2014. The utilized the unit root tests, the autoregressive vector (VAR) model, and the Wald test to test causality. Their results showed that the series are all I (1) and that there is no long-term relationship. Also, there was a bidirectional causality relationship between gasoline consumption and economic growth in Cameroon. This implies that an increase in gasoline consumption affects economic growth with feedback effect. In view of the result of causality, reducing gasoline consumption without appropriate and established energy policies is not a feasible situation to maintain Cameroon's economic growth. Khobai (2017) investigates the causal relationship between renewable energy consumption and economic growth in South Africa. It incorporates carbon dioxide emissions, capital formation and trade openness as additional variables to form a multivariate framework. Quarterly data was used for the period $1990-2014$ and is tested for stationarity using the Augmented Dickey Fuller (ADF), Dickey Fuller Generalized Least Squares (DF-GLS), Phillips, and Perron (PP) unit root tests. The study employs the Autoregressive distributed lag (ARDL) model to examine the long run relationship among the variables. Lastly, the study determines the direction of causality between the variables using the Vector Error Correction Model (VECM). The results validated an existence of a long run relationship between the variables. Moreover, a unidirectional causality flowing from renewable energy consumption to economic growth was established in the longrun. The short run results suggested a unidirectional causality flowing from economic growth to renewable energy consumption. The findings of the study suggest that an appropriate and effective public policy is required in the longrun, while considering sustainable economic growth and development.

Amri (2017) examined the relationship between economic growth and energy consumption under two categories- renewable and non-renewable energy consumption. The findings from the ARDL model supported a long run relationship between economic growth and non-renewable energy consumption but no co-integration was found between renewable energy consumption and economic growth. The results posited bidirectional causality between non-renewable energy consumption and economic growth both in the short run and long run. Furthermore, the results revealed a unidirectional causality flowing from renewable energy consumption to economic growth in the longrun. Marinaș, Dinu, Socol and Socol (2018) tested the correlation between economic growth and renewable energy consumption for ten European Union (EU) member states from Central and Eastern Europe (CEE) in the period 1990 to 2014, using Autoregressive and Distributed Lag (ARDL) modeling procedure, a technique that captures causal relationships both on a short run and on a long run. They found that in the short run, the Gross Domestic Product (GDP) and Renewable Energy Consumption (REC) dynamics are independent in Romania and Bulgaria, while in Hungary, Lithuania, and Slovenia an increasing renewable energy consumption improves the economic growth. The hypothesis of bi-directional causality between renewable energy consumption and economic growth is validated in the long run for both the whole group of analyzed countries as well as in the case of seven CEE states which were studied individually.

Maji, Chindo, and Rahim (2019)'s study was on Renewable energy consumption and economic growth nexus: A fresh evidence from West Africa. They estimated the impact of renewable energy on economic growth in West African countries using panel dynamic ordinary least squares (DOLS) by employing a sample of 15 West African countries covering the 1995 to 2014 period. Their results indicated that renewable energy consumption slows down economic growth in these countries. This, they attributed to the nature and source of renewable energy used in West Africa, which is majorly wood biomass. The 
wood biomasses used in West Africa are usually unclean and highly polluting when burnt. On the other hand, the use of clean energy sources like solar, wind and hydropower which does not have a side effect on human health and the environment is less in West Africa. As such, renewable energy use can slow down economic growth by lowering productivity when unclean and inefficient sources are used. Khan, Khan, and Rehan, (2020) investigated the relationship between energy consumption, economic growth and carbon dioxide emissions in Pakistan using annual time series data from 1965 to 2015. Their estimated results of ARDL indicate that energy consumption and economic growth increase the $\mathrm{CO} 2$ emissions in Pakistan both in short run and long run. Based on the estimated results they recommended that policy maker in Pakistan should adopt and promote such renewable energy sources that will help to meet the increased demand for energy by replacing old traditional energy sources such as coal, gas, and oil. Renewable energy sources are reusable that can reduce the $\mathrm{CO} 2$ emissions and also ensure sustainable economic development of Pakistan.

Given the review above, it can be concluded that the studies for the economic growth - renewable energy consumption nexus or economic growth renewable electricity consumption nexus remains inconclusive as mixed results were found among the various studies. This variation in the results may be attributed to several characteristics as estimation techniques, model specification, data characteristics and development level of the country, Sebri (2015).

\section{Stylized facts on Nigeria's Energy Resources}

Nigeria have huge energy resources, which potentially give the country ample opportunity to transform her economy and the lives of her citizens. Nigeria sits astride of over 35 billion barrels of oil, 187trillion cubic feet of gas, 4 billion metric tons of coal and lignite, as well as huge reserves of tar sands, hydropower, and solar radiation, among others (Adenikinju, 2008). For understandable reasons, Nigeria has not devoted equal attention to her abundant energy resources. Her efforts have been concentrated on the development, exploitation and utilization of crude oil and gas for fiscal objectives.

\section{Oil}

Nigeria has an estimated 37.2 billion barrels of proven oil reserves as of the end of 2011. The majority of reserves are found along the country's Niger River Delta and offshore in the Bight of Benin, the Gulf of Guinea, and the Bight of Bonny. Current exploration activities are mostly focused in the deep and ultra-deep offshore with some activities in the Chad basin, located in the northeast of the country. The government hopes to increase proven oil reserves to 40 billion barrels in the next few years. Nigeria has four refineries with a total installed capacity of 445,000 barrels per day. However, capacity utilization is low. Consequently, annual consumption of petroleum products, which according to government figures stood at 34 million liters per day, is not fully met by internal production and has to be supplemented by imports.

\section{Natural Gas}

Nigeria's proven natural gas reserves, estimated at about 187 trillion standard cubic feet, are known to be substantially larger than its oil resources in energy terms. Gas discoveries in Nigeria are incidental to oil exploration and production activities. As of 2001 , over $50 \%$ of the gas produced (mainly associated gas) was flared. In view of the increasing domestic oil consumption, an economically optimal strategy to replace oil with gas and gas derivatives will enhance the availability of more oil for export. This will also promote the conservation of the oil reserves. Apart from the economic advantage, fuel substitution from oil togas is more environmentally friendly because gas is a cleaner fuel than oil. Given the current reserves and rate of exploitation, the expected life-span of Nigerian crude oil is about 44 years, based on about $2 \mathrm{mb} / \mathrm{d}$ production, while that for natural gas is about 88 years, based on the 2001 production rate of 1850 bscf. It is, therefore, strategically important to undertake major investments in the gas sector in order to prepare adequately for gas as a substitute for oil both for domestic needs and foreign exchange earnings.

\section{Coal}

Recent technical and economic studies have identified coal energy as a cost effective solution for power generation; it comes at a cost that is about $20 \%$ that of fuel oil and with the cost of crude oil heading towards US $\$ 100$ per barrel, the gap will continue to widen. Furthermore, with over two billion tons 
reserves in Nigeria, coal is an abundant domestic resource that can support the mining and energy industries and provide numerous jobs with potentially high multiplier effects on the local economy. Current technologies allow for clean burning of coal, which takes care of its negative environmental impact; indeed over $50 \%$ of the US electrical power supply is from coal resources. Nigerian coal can be utilized for power generation, steam production, in cement production and for brick making; as a heat source and reducing agent for steel production; as a domestic fuel; and as feedstock for the production of chemicals, liquid fuels, gaseous fuels, batteries, carbon electrodes etc. Nwasike and Gregory, (2003). These potentials of coal need to be effectively harnessed into the country's energy delivery system and export commodity mix through the development of a vibrant coal industry. Coal is an alternative energy medium that could be used with oil and gas to give the nation the desired mix that will ensure a reliable, affordable, and environmentally friendly energy medium.

\section{Electricity}

Commercial electricity is generated mainly from hydropower, steam plants and gas turbines in Nigeria. Between 1985 and 2000, electricity generation capacity grew by a mere 10 per centin Nigeria compared to 332 per cent in Vietnam, 142 per cent in Iran, 237 per cent in Indonesia, 243 per cent in Malaysia and 205 per cent in South Korea (Maigida, 2008). Electricity generation capacity is also far below compared countries. Nigeria, with a population of over 170 million people, has an installed generation capacity of $6000 \mathrm{MW}$ compared to UAE $4740 \mathrm{MW}$ to a population of 4 million or South Africa that has 46000MW to44million people.

\section{Biomass}

Organic, non-fossil material of biological origin is called biomass. The biomass resources of Nigeria can be identified as wood, forage grasses and shrubs, animal wastes and wastes arising from forestry, agricultural, municipal, and industrial activities, as well as aquatic biomass. The biomass energy resources of the nation have been estimated to be significant. Plant biomass can be used as fuel in thermal power plants or converted to produce solid briquettes, which can then be utilized as fuel for small-scale industries. Biogas digesters of various designs are capable of sustaining household, industrial and institutional energy needs. It has indeed been shown that the remaining biomass material after digestion is a better fertilizer than the original waste. The intensive application of this will reduce the existing heavy reliance on chemical fertilizers. The abundant energy available from biomass can be meaningfully introduced into the nation's energy mix through the development of a comprehensive programme. The programme should encompass fully supported research, development, demonstration, and manpower training components.

\section{Methodology and Data Source Model Specification}

This study aimed at establishing the dynamics properties of the relationship between Renewable Energy Consumption (REC), and Economic Growth proxy by Real Gross Domestic Product (RGDP) in Nigeria over the years (1990 to 2016). The functional form, on which the model is based, employed simple regression equation in the analysis of this work. In an attempt to capture the crux of this study, the model is represented in a functional form as shown below:

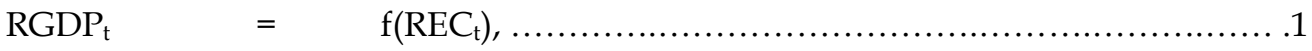

Stating equation (3.1) in the linear explicit form yields:

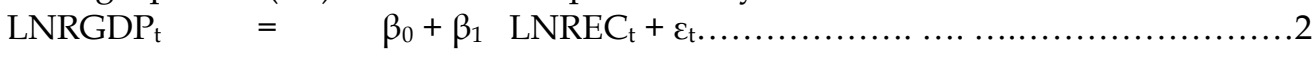

Expressing equation (3.2) in log linear form yields

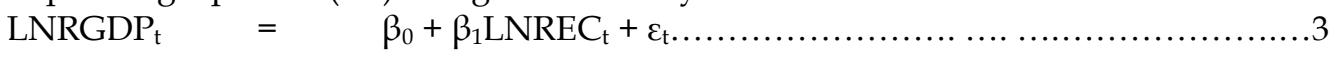

Where:

RGDP $_{\mathrm{t}}$ is Real Gross Domestic Product at time $\mathrm{t}$

$\mathrm{REC}_{\mathrm{t}}$ is Renewable Energy Consumption at time $t$

LNRGDP $_{\mathrm{t}}$ is Log of Real Gross Domestic Product at time $\mathrm{t}$

LNREC $_{t}$ is Log of Renewable Energy Consumption at time $t$ 
$\varepsilon_{t} \quad$ is the stochastic error term

it is Time trend (1990-2016)

$\beta_{0,}$ and $\beta_{1, \text { is }}$ are intercept and slope coefficients to be estimated.

\section{The 'a Priori' Expectation}

The a-priori expectation regarding the relationship among the independent variables and the dependent variable is that; $\beta_{0}>0$ indicating that at zero renewable energy consumption RGDP is greater than zero. $\beta_{1}>0$ a positive relationship between renewable energy consumption and economic growth, that is, increase/decrease in renewable energy consumption leads to increase or decrease in economic growth ceteris paribus.

Causality Model Specification

The pair-wise bivariate causality model is as present below:

$\operatorname{LnRGDP}_{t}=\sum_{i=1}^{n} \alpha_{i} \operatorname{LnRGDP}_{t}+\sum_{i=1}^{n} \beta_{i} \operatorname{LnREC}_{t}+\varepsilon_{t} \ldots \ldots \ldots \ldots \ldots$

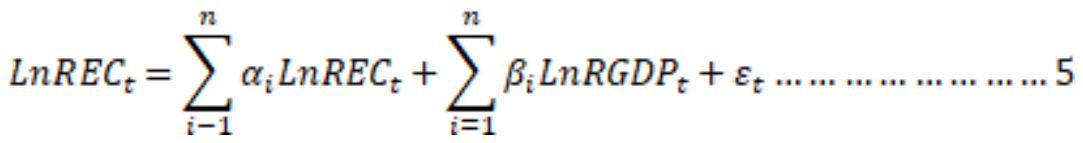

In Equation 4 current LNRGDP was related to its past values as well as past values of LNREC. On the other hand, equations 5 postulated that LNREC was related to its past values as well as past values of LNRGDP. If $\beta_{1}, \beta_{2}, \ldots, \beta_{\mathrm{k}}=0$ in equation 4 implied LNREC does not Granger Cause LNRGDP. Similarly, if $\beta_{1}, \beta_{2}, \ldots, \beta_{\mathrm{k}}=0$ in equation 5 implied LNRGDP does not Granger Cause LNREC.

\section{Data Source}

This study made use of secondary annual data for Nigeria for the period 1990 to 2016. The data for the study was sourced from the Central Bank of Nigeria (CBN) 2016 Statistical Bulletin (for RGDP) as well as the U.S. Energy Information Administration for renewable energy consumption for (REC).

\section{Data Analysis}

\section{Descriptive Statistics}

The results for the Mean, a measure of central tendency, Standard Deviation, a measure of dispersion or variability, maximum or peak value and minimum or lowest value is as presented in table below:

Table 4.1 Descriptive Statistics

\begin{tabular}{|l|l|l|}
\hline & RGDP & REC \\
\hline Mean & 37274.79 & 3098868. \\
\hline Median & 31709.45 & 2997940. \\
\hline Maximum & 69023.93 & 4206286. \\
\hline Minimum & 19199.06 & 2145327. \\
\hline Std. Dev. & 17796.49 & 676437.8 \\
\hline Skewness & 0.563305 & 0.278251 \\
\hline Kurtosis & 1.814241 & 1.754103 \\
\hline & & \\
\hline Jarque-Bera & 3.009684 & 2.094699 \\
\hline Probability & 0.222052 & 0.350866 \\
\hline & & \\
\hline Sum & 1006419. & 83669448 \\
\hline Sum Sq. Dev. & $8.23 \mathrm{E}+09$ & $1.19 \mathrm{E}+13$ \\
\hline & & \\
\hline Observations & 27 & 27 \\
\hline
\end{tabular}

Source: Computed by the Authors using E-views 9 
From the table, the average real gross domestic product (RGDP) from 1990 to 2016 is 37,274.79 billion naira. This is as shown by the mean value for real gross domestic product for the 27-year period of the study. The average value for renewable energy consumption (REC) is 3,098,868 Gigawatt hours. It is also clearly showed that the peak value for real gross domestic product (RGDP) is 69,023.93 billion naira. This occurred in year 2015. In addition, peak value for renewable energy consumption (REC) is 4,206,286 Gigawatt hours. This also occurred in year 2016. These values are as shown by their respective maximum values. However, the lowest value for real gross domestic product (RGDP) and renewable energy consumption (REC) is 19,199.06 billion naira and 2,145,327 as shown by their minimum values respectively. These values both occurred in year 1990, which is the early year of the study. The standard deviation indicates the spread of the variable around it means. It is a measure of spread and variability. The standard deviation for RGDP and REC is $17,796.46$ and $676,437.8$, respectively. The normality distribution of the data sets was tested using Jarque-Bera statistics, the test showed that are not normally distributed at $10 \%$ and $1 \%$ respectively. This implies that REC has high level of volatility when compared to the RGDP.

\section{Correlation Analysis}

In this section we discuss correlation analysis, which is used to quantify the association between two continuous variables (e.g., between an independent and a dependent variable or between two independent variables). In correlation analysis, we estimate a sample correlation coefficient, more specifically the Pearson Product Moment correlation coefficient. The sample correlation coefficient, denoted $r$, ranges between -1 and +1 and quantifies the direction and strength of the linear association between the two variables. The correlation between two variables can be positive (i.e., higher levels of one variable are associated with higher levels of the other) or negative (i.e., higher levels of one variable are associated with lower levels of the other). The analysis continues in this section in determining the degree of linear association between RGDP and the independent variable, REC. The result of the correlation analysis is presented in table below.

Table 4.2: Correlation Matrix between the Variables

\begin{tabular}{|c|l|l|}
\hline & LNRGDP & LNREC \\
\hline LOGRGDP & 1.000000 & 0.759589 \\
\hline LOGREC & 0.759589 & 1.000000 \\
\hline
\end{tabular}

Source: Computed by the Authors using E-Views 9

It is evident from table 4.2 above that there is a strong positive relationship between real gross domestic product (RGDP) and renewable energy consumption (REC) during the period of the study. This is indicated by the high Pearson Correlation Coefficient of 0.759589, implying that with increase renewable consumption energy there is more opportunity for increased economic activities and hence an increase in real gross domestic product (RGDP) and growth.

\section{Empirical Analysis \\ Unit root Test or Test of Stationarity}

This section presents the unit root test result. The unit root test was conducted to help avoid "spurious" or "nonsense" regression results. Most time series variables are usually non-stationary and using non-stationary variables in the model might lead to spurious regressions (Granger and New bold, 1977 and in

Yule 1926). Hence the variables were tested at levels, first and second difference for stationarity using the Augmented Dickey-Fuller (ADF) test. The result is presented below: 
Table 4.3: Results of Augmented Dickey-Fuller Unit Root Tests

\begin{tabular}{|c|c|c|c|c|}
\hline \multirow[b]{2}{*}{ Test in: } & \multicolumn{2}{|c|}{$\begin{array}{l}\text { ADF Test Statistics and Mackinnon } \\
\text { (1996) one-sided P-values for the } \\
\text { Variables in brackets }\end{array}$} & \multicolumn{2}{|c|}{ Makinnon Critical Values at $5 \%$} \\
\hline & LNRGDP & LNREC & LNRGDP & LNREC \\
\hline Level & $\begin{array}{l}-1.122466 \\
(0.6904)\end{array}$ & $\begin{array}{l}1.227719 \\
(0.9973)\end{array}$ & -2.986225 & -3.004861 \\
\hline 1st Difference & $\begin{array}{l}-1.929053 \\
(0.3144)\end{array}$ & $\begin{array}{l}-2.998064^{*} \\
(0.0020)\end{array}$ & -2.986225 & -3.020686 \\
\hline 2nd Differnce & $\begin{array}{l}-5.226688^{*} \\
(0.0003)\end{array}$ & $\begin{array}{l}-2.245140 \\
(0.1975)\end{array}$ & -2.991878 & -3.004861 \\
\hline $\begin{array}{l}\text { Order of } \\
\text { Integration }\end{array}$ & $\mathrm{I}(2)$ & $\mathrm{I}(1)$ & & \\
\hline
\end{tabular}

* Significant at 5 per cent Level of Significance (LOS). ADF is calculated with intercept using Lag Length: 1 (Automatic - based on SIC, maxlag=5)

Source: Computed by the Authors using E-Views 9

The unit root was done using the Augmented Dickey-Fuller (ADF) test, (including test with intercept and a one period lag). The summary of results for the unit root test as tabulated in table 4.3 above have shown that both variables have unit root, that is, they are non-stationary, at levels, This is because their ADF statistic values are all less than the Mackinnon critical table values in absolute term at the 5 per cent level of significance (LOS). Alternatively, the Mackinnon p-value in the bracket is more than 5 percent. Thus, the null hypothesis of non-stationarity could not be rejected when the test is done at level for the two variables. Consequently, the ADF test strongly support the hypothesis that both variables are non-stationary at level and that they exhibit a random walk.

This suggested the need to difference the series to obtain stationarity. The immediate conclusion is that any dynamic specification of the model in the levels of the series is likely to be inappropriate and may be affected by problems of "nonsense" regression or "spurious" regression. After the $2^{\text {nd }}$ difference, LNRGDP become stationary as shown by the bold asterisk values in the table. Hence, it is integrated of order two I (2). LNREC on the other hand is stationary at first difference meaning it is integrated of order one I (1). So, the unit root test was re-tested by differencing the LNRGDP so as to derive I (1) of REC and I (1) in order to test further for co-integration. The result of the unit root after differencing RGDP(LNDRGDP) and logging it to derive integrated of order I(1) and logging of REC (LNREC) now remain at integrated of order I(1) was significant at first difference where LNDRGDP at first difference is 0.0001 and LNREC is 0.0020 . The result showed that the unit test was stationary at first difference and has no unit root so null hypothesis is rejected.

\section{Co-integration Test}

The result of the co-integration test in table 4.4 below at $5 \%$ level was set that the series are not cointegrated, so we rejected the null hypothesis.

Table 4.4: Result of Cointegration Test

\begin{tabular}{llccr}
\hline \hline & & & & \\
Dependent & tau-statistic & Prob. $^{*}$ & Z-statistic & Prob. $^{*}$ \\
\hline LOGDRGDP & -3.126603 & 0.1202 & -15.04498 & 0.0705 \\
LOGREC & -2.130230 & 0.4750 & -9.176176 & 0.3333 \\
\hline \hline
\end{tabular}

*MacKinnon (1996) p-values.

Intermediate Results:

\begin{tabular}{lcc} 
& LOGDRGDP & LOGREC \\
\hline Rho -1 & -0.654129 & -0.398964 \\
Rho S.E. & 0.209214 & 0.187287
\end{tabular}




$\begin{array}{lll}\text { Residual variance } & 0.571765 & 4.92 \mathrm{E}-05 \\ \text { Long-run residual variance } & 0.571765 & 4.92 \mathrm{E}-05 \\ \text { Number of lags } & 0 & 0 \\ \text { Number of observations } & 23 & 23 \\ \text { Number of stochastic trends** } & 2 & 2\end{array}$

${ }^{* *}$ Number of stochastic trends in asymptotic distribution

\section{Regression Analysis}

One of the objectives of this study is to determine the relationship between renewable energy consumption and economic growth in Nigeria. To carry out this objective a simple regression analysis using ordinary least squares (OLS) was conducted and the result is as presented in table 4.6.1 below for scale effect and a more robust regression result the natural logarithms of the data presented in appendix II were employed for the regression analysis.

Table 4.5: Regression Results

\begin{tabular}{lllll}
\hline \hline Variable & Coefficient & Std. Error & t-Statistic & Prob. \\
\hline \hline C & 0.392074 & 0.660154 & 0.593913 & 0.5596 \\
D(LOGREC) & -155.3216 & 348.1863 & -0.446088 & 0.6606 \\
D (LOGDRGDP (-1)) & -0.293674 & 0.222822 & -1.317974 & 0.2032 \\
\hline \hline R-squared & 0.089317 & Mean dependent var & 0.082039 \\
Adjusted R-squared & -0.006545 & S.D. dependent var & 0.920345 \\
S.E. of regression & 0.923352 & Akaike info criterion & 2.804512 \\
Sum squared resid & 16.19900 & Schwarz criterion & 2.953290 \\
Log likelihood & -27.84963 & Hannan-Quinn criter. & 2.839559 \\
F-statistic & 0.931727 & Durbin-Watson stat & 1.887898 \\
Prob(F-statistic) & 0.411140 & & \\
\hline \hline
\end{tabular}

Source: Computed by the Authors using E-Views 9

The estimated regression result can be represented as below:

LNDRGDP $=0.392074-(155.3216)$ LNREC 6

The regression result shows that the coefficient of LNREC is negative, this means that $\beta_{1}<0$ and this conforms to the a priori expectation of the model for the study. This result can be interpreted as a decrease (increase) in LNREC leads to decrease (increase) in real gross domestic product. This is as the same as the correlation and Granger causality results. The coefficient of LNREC is -155.3216 meaning a percentage decrease (increase) in LNREC leads to about -155 percent decrease (increase) in LNDRGDP; this is because the variables are already in logarithm form. In addition, the t-statistic of -0.446088 is low enough and the probability value of 0.6606 is high enough, indicating that the coefficient of LNREC is not statistically significant at 5 percent level of significance (LOS). The $R_{2}$ of 0.089317 shows that 8.93 percent variation in the dependent variable (LNDRGDP) is explained by the independent variable (LNREC), leaving the remaining 91.07 percent to other variables not captured by the model. In addition, the F-statistics and Fstatistical probability of 0.931727 and 0.411140 respectively are highly plausible indicate that overall, the model is not statistically significant at one percent level of significance. However, the Durbin-Watson statistic of 1.887898 is not desirable as it indicates that there is no serial correlation in the series because; Durbin Watson is in the neigbourhood of 2.

\section{Granger Causality Test}

The analysis continues in this section with a test of causality between the variables. Employing Eviews 9 statistical package, from the data in Appendix I, the pair-wise Granger causality test were examined. The result is as presented in table 4.8 .1 below. 
Table 4.6: Granger Causality Test Results

\begin{tabular}{|l|l|l|l|}
\hline Null Hypothesis: & Obs & F-Statistic & Prob. \\
\hline LOGREC does not Granger Cause LOGDRGDP & 22 & 1.70822 & 0.2109 \\
\hline LOGRGDP does not Granger Cause LOGREC & & 0.92443 & 0.4158 \\
\hline
\end{tabular}

Source: Computed by the Authors using E-Views 9

From the above result, there was no causality between the two variable RGDP and REC. The null hypothesis REC does not Granger cause RGDP was accepted while the second null hypothesis, RGDP does not Granger Cause REC was also accepted for the two Lag period considered at $5 \%$ level of the set probability 0.2109 and 0.4158 are not significant.

\section{Summary and Conclusion}

This study empirically examined the relationship between renewable energy consumption and economic growth in Nigeria (1990-2016). The major objective of this study is to determine the impact of renewable energy consumption on economic growth in Nigeria. The data used in this study are secondary data. The variables that were used include the dependent variable; RGDP in constant 2010 basic prices, (RGDP) as proxy for economic growth and the independent variable is renewable energy consumption defined in billions of kilowatt hours (REC). Unit root was conducted using the Augmented Dickey-Fuller (ADF) test. The results for the unit root test have shown that both variables have unit root, that is, they are non-stationary, at levels, and that they exhibit a random walk. This suggests the need to difference the series to obtain stationarity. RGDP become stationary at 1st difference hence, it is integrated of order one I (1). REC on the other hand is stationary at first difference meaning it is integrated of order one I (1). From the correlation analysis, it is evident that there is a strong and significant positive relationship between economic growth and renewable energy consumption (REC) during the period of the study. From the Granger causality result, there is no causality between real gross domestic product and renewable energy consumption. The granger causality test negates apriori expectation positive relationship between the renewable energy consumption and economic growth in Nigeria. As a result, renewable energy consumption leads to economic growth in the long-un. The regression result shows that the coefficient of renewable energy consumption (REC) negate to the a priori expectation of positive relationship between renewable energy consumption and economic growth in Nigeria. The result showed a negative but not significant relationship.

It is believed that the greater the renewable energy consumption, the more the economic activity in the nation and as a result a greater economy emerges. But, based on the empirical results, this study concludes that there is no significant and positive long-run relationship exists between renewable energy consumption and economic growth in Nigeria. This might be attributed to the fact that Nigeria though, heavily reliant on energy, the use of these renewable resources tends to be negligible and this might be a major factor in the result gotten by the study. Thus, we recommend that policies should focus more on increasing the use and efficiency of this renewable energy. Investing in renewable energy should be encouraged and enhanced as this may be a way to reduce domestic fossil fuel consumption or to meet increasing energy demand without an increase of domestic fuel consumption to increase fuel exports and thus for higher revenues as well as enhance economic growth.

\section{References}

Adenikinju, A. (2008): Efficiency of the energy sector and its impact on the competitiveness of the Nigeria economy. Int. Association for Energy Economics Fourth Quarter, pp. 27-31.

https://www.iaee.org/documents/newsletterarticles/408adeola.pdf

Aminu, M. M. and Aminu, M. F. (2015). Energy consumption and economic growth in Nigeria: A causality analysis. Journal of Economics and Sustainable Development www.iiste.org Vol.6, No.13.

Amri, F. (2017): Intercourse across economic growth, trade, and renewable energy consumption in developing and developed countries. Renewable and Sustainable Energy Reviews, 69, pp.527-534.

Apergis, N, and Danuletiu, D. (2014). Renewable energy and economic growth: Evidence from the sign of panel longrun causality. International Journal of Energy Economics and Policy 4(4), 578-587. Retrieved from http://www.econjournals.com/index.php/ijeep/article/viewFile/879/515 
Canning, David and Pedroni, Peter L., (2008). Infrastructure, Long-Run Economic Growth and Causality Tests for Cointegrated Panels. Manchester School, Vol. 76, Issue 5, pp. 504-527, September. Available at SSRN: https://ssrn.com/abstract=1230304 or http://dx.doi.org/10.1111/j.1467-9957.2008.01073.x

Halkos, G.E. and Tzeremes, N.G., 2014. The effect of electricity consumption from renewable sources on countries economic growth levels: Evidence from advanced, emerging and developing economies. Renewable and Sustainable Energy Reviews, 39, pp.166-173.

International Energy Agency (IEA, 2015a) “WEO 2015 Electricity access database”. Retrieved from

http://www.worldenergyoutlook.org/resources/energydevelopment/energyaccessdatabase/

International Energy Agency (IEA, 2015b) “Energy and Climate Change”. Retrieved from

http:/ / www.worldenergyoutlook.org/energyclimate/

Jebli, Ben, M., and Ben Youssef, S. (2015). Economic growth, combustible renewables and waste consumption, and CO2 emissions in North Africa. Environmental Science and Pollution Research 22, 16022-16030. https://doi.org/10.1007/s11356-015-4792-0

Kazar, G., Kazar, A., (2014), The Renewable energy production-economic development nexus, International Journal of Energy Economics andPolicy, 4 (2), 312-319.

Khan, M.K., Khan, M.I. \& Rehan, M. (2020). The relationship between energy consumption, economic growth, and carbon dioxide emissions in Pakistan. Financial Innovation 6, 1. https:/ / doi.org/10.1186/s40854-019-0162-0

Khobai, H. (2017): Does renewable energy consumption drive economic growth: Evidence from Granger-causality technique. https://2017.essa.org.za/fullpaper/essa_3526.pdf

Leitao, N. C., (2014), Economic growth, carbon dioxide emissions, renewable energy and globalization, International Journal of Energy Economics and Policy, 4 (3), 391-399

Lin, H. (2014). Renewable energy consumption and economic growth in nine OECD countries: Bounds test approach and causality analysis. The Scientific World Journal 2014. Retrieved

From http:/ /www.hindawi.com/journals/tswj/2014/919167/

Maigida, S. (2008, April). Power sector infrastructural development by 2020: issues and challenges. Paper Presented at the $1^{\text {st }}$ International Conference of NAEE/IAEE. Transcorp Hilton Hotel, 29th - 30th of April.

Maji, Ibrahim, Sulaiman Chindo, and Rahim Abdul (2019). Renewable energy consumption and economic growth nexus: A fresh evidence from West Africa. Energy Reports, Volume 5, March. DOI: 10.1016/j.egyr.2019.03.005

Marinaș M-C, Dinu M, Socol A-G, Socol C (2018) Renewable energy consumption and economic growth. Causality relationship in Central and Eastern European countries. PLoS ONE 13(10): e0202951

. https://doi.org/10.1371/journal.pone.0202951

Nwasike, Obi and Oranugo Gregory, (2003). Opportunities and Challenges of an Integrated Energy Policy for Nigeria - Perspectives from a competing Energy Product. Proceedings of the Nigeria Annual International Conference and Exhibition, 4-6 August, Abuja, Nigeria. DOI: 10.2118/85670-MS

Odularu, G.O. and Okonkwo, C. (2009). Does energy consumption contribute to economic performance? Empirical evidence from Nigeria: East-West Journal of Economics and Business Vol. XII, No 2

Ogundipe, A. A. and Apata, A. (2013). Electricity consumption and economic growth in Nigeria. Journal of Business Management and Applied Economics 1 Vol. II, Issue 4 July. Scientific Papers (www.scientificpapers.org)

Omri, A., Mabrouk, N.B. and Sassi-Tmar, A., 2015.Modeling the causal linkages between nuclear energy, renewable energy, and economic growth in developed and developing countries. Renewable and Sustainable Energy Reviews, 42, pp.1012-1022.

Pao, H.T. and Fu, H.C. (2013) Renewable Energy, Non-Renewable Energy and Economic Growth in Brazil. Renewable and Sustainable Energy Reviews, 25, 381-392.http://dx.doi.org/10.1016/j.rser.2013.05.004

Renewable Energy Policy Network for the 21st Century (REN 21) (2015) Renewables 2015 global status report. Retrieved from

http:/ / www.ren21.net/wp-content/uploads/2015/07/REN12-GSR2015_Onlinebook_low1.pdf

Sari, Ramazan, Bradley Ewing, T., Uger Soytas, (2008), The relationship between disaggregate energy consumption and industrial production in the United States: An ARDL approach. Energy Economics, 30 (5): $2302-2313$. September. DOI: 10.1016/j.eneco.2007.10.002

Sebri, M., (2015), Use renewables to be cleaner: Meta-analysis of the renewable energy consumption-economic growth nexus, Renewable and Sustainable Energy Reviews, 42, 657-665.

Tamba, Jean Gaston, Jean Luc Nsouandélé \& Armand Fopah Lélé (2017) Gasoline consumption and economic growth: Evidence from

Cameroon, Energy Sources, Part B: Economics, Planning, and Policy, 12:8, 685-

691, DOI: $10.1080 / 15567249.2016 .1269140$

United Nations Environment Program (UNEP) (2015) “Global trends in renewable energy investment 2015 Report”. Retrieved from: 
https://wedocs.unep.org/bitstream/handle/20.500.11822/9403/Global_trends_in_renewable_energy_investment_20 15-201515028nefvisual8-mediumres.pdf.pdf?sequence $=3 \& a m p \% 3 B i s$ Allowed $=$

World watch Institute, (2005) "Energy for development the potential role of renewable energy in meeting the millennium development goals". Retrieved from http://www.worldwatch.org/system/files/ren21-1.pdf

Yildirim, Ertgrul, Senay Sarac, Alper Aslan, (2012). Energy consumption and economic growth in the USA: Evidence from renewable energy. Renewable and Sustainable Energy Review, 16(9), 6770-6774. December. DOI: 10.1016/j.rser.2012.09.004

\section{Appendix: Unit Root Test Results}

\section{LNRGDP Unit Root Test Result at Level}

Null Hypothesis: LOGRGDP has a unit root

Exogenous: Constant

Lag Length: 1 (Automatic - based on SIC, maxlag=6)

\begin{tabular}{|c|c|c|c|}
\hline & & t-Statistic & Prob. ${ }^{*}$ \\
\hline \multicolumn{2}{|c|}{ Augmented Dickey-Fuller test statistic } & -1.122466 & 0.6904 \\
\hline \multirow[t]{3}{*}{ Test critical values: } & $1 \%$ level & -3.724070 & \\
\hline & $5 \%$ level & -2.986225 & \\
\hline & $10 \%$ level & -2.632604 & \\
\hline
\end{tabular}

*MacKinnon (1996) one-sided p-values.

Augmented Dickey-Fuller Test Equation

Dependent Variable: D(LOGRGDP)

Method: Least Squares

Date: 08/05/18 Time: 10:06

Sample (adjusted): 19922016

Included observations: 25 after adjustments

\begin{tabular}{lllll}
\hline \hline Variable & Coefficient & Std. Error & t-Statistic & Prob. \\
\hline \hline LOGRGDP (-1) & -0.014520 & 0.012936 & -1.122466 & 0.2738 \\
D (LOGRGDP (-1)) & 0.786178 & 0.172513 & $\begin{array}{l}4.557208 \\
1.232924\end{array}$ & 0.0002 \\
C & 0.161659 & 0.131118 & 0.2306 \\
\hline \hline R-squared & 0.497502 & Mean dependent var & 0.050545 \\
Adjusted R-squared & 0.451820 & S.D. dependent var & 0.034892 \\
S.E. of regression & 0.025834 & Akaike info criterion & -4.362087 \\
Sum squared resid & 0.014683 & Schwarz criterion & -4.215822 \\
Log likelihood & 57.52609 & Hannan-Quinn criter. & -4.321520 \\
F-statistic & 10.89064 & Durbin-Watson stat & 2.079293 \\
Prob(F-statistic) & 0.000516 & & \\
\hline \hline
\end{tabular}

\section{LNDRGDP Unit Root Test Result at First Difference}

Null Hypothesis: LOGRGDP has a unit root

Exogenous: Constant

Lag Length: 1 (Automatic - based on SIC, maxlag=6)

\begin{tabular}{lccc}
\hline \hline & t-Statistic & Prob. $^{*}$ \\
\hline \hline \multicolumn{2}{l}{ Augmented Dickey-Fuller test statistic } & -1.122466 & 0.6904 \\
\hline Test critical values: & 1\% level & -3.724070 & \\
& 5\% level & -2.986225 & \\
& $10 \%$ level & -2.632604 & \\
\hline \hline
\end{tabular}

*MacKinnon (1996) one-sided p-values. 


\begin{tabular}{|c|c|c|c|c|}
\hline $\begin{array}{l}\text { Augmented Dickey-1 } \\
\text { Dependent Variable: } \\
\text { Method: Least Squar } \\
\text { Date: 08/05/18 Tim } \\
\text { Sample (adjusted): } 19 \\
\text { Included observation }\end{array}$ & $\begin{array}{l}\text { Test Equation } \\
\text { GRGDP) } \\
6 \\
6 \\
\text { fter adjustme }\end{array}$ & & & \\
\hline Variable & Coefficient & Std. Error & $\mathrm{t}$-Statistic & Prob. \\
\hline LOGRGDP (-1) & -0.014520 & 0.012936 & -1.122466 & 0.2738 \\
\hline D (LOGRGDP $(-1))$ & 0.786178 & 0.172513 & 4.557208 & 0.0002 \\
\hline $\mathrm{C}$ & 0.161659 & 0.131118 & 1.232924 & 0.2306 \\
\hline R-squared & 0.497502 & Mean de & lent var & 0.050545 \\
\hline Adjusted R-squared & 0.451820 & S.D. dep & nt var & 0.034892 \\
\hline S.E. of regression & 0.025834 & Akaike i & riterion & -4.362087 \\
\hline Sum squared resid & 0.014683 & Schwarz & rion & -4.215822 \\
\hline Log likelihood & 57.52609 & Hannan & in criter. & -4.321520 \\
\hline F-statistic & 10.89064 & Durbin- & on stat & 2.079293 \\
\hline Prob(F-statistic) & 0.000516 & & & \\
\hline
\end{tabular}

\section{LNRGDP Unit Root Test Result at Second Difference}

Null Hypothesis: D(LOGRGDP) has a unit root

Exogenous: Constant

Lag Length: 0 (Automatic - based on SIC, maxlag=5)

\begin{tabular}{lccc}
\hline \hline & & t-Statistic & Prob.* \\
\hline \hline \multicolumn{2}{l}{ Augmented Dickey-Fuller test statistic } & -1.929053 & 0.3144 \\
\hline Test critical values: & 1\% level & -3.724070 & \\
& 5\% level & -2.986225 & \\
& 10\% level & -2.632604 & \\
\hline \hline
\end{tabular}

*MacKinnon (1996) one-sided p-values.

Augmented Dickey-Fuller Test Equation

Dependent Variable: D(LOGRGDP,2)

Method: Least Squares

Date: 08/05/18 Time: 10:14

Sample (adjusted): 19922016

Included observations: 25 after adjustments

\begin{tabular}{lllll}
\hline \hline Variable & Coefficient & Std. Error & t-Statistic & Prob. \\
\hline \hline D (LOGRGDP (-1)) & -0.299835 & 0.155431 & -1.929053 & 0.0662 \\
C & 0.014863 & 0.009473 & 1.568993 & 0.1303 \\
\hline \hline R-squared & 0.139262 & Mean dependent var & -0.000417 \\
Adjusted R-squared & 0.101838 & S.D. dependent var & 0.027413 \\
S.E. of regression & 0.025980 & Akaike info criterion & -4.386398 \\
Sum squared resid & 0.015524 & Schwarz criterion & -4.288888 \\
Log likelihood & 56.82997 & Hannan-Quinn criter. & -4.359353 \\
F-statistic & 3.721247 & Durbin-Watson stat & 1.835265 \\
Prob(F-statistic) & 0.066153 & & \\
\hline \hline
\end{tabular}




\section{LNDRGDP Unit Root Test Result at Level}

Null Hypothesis: LOGDRGDP has a unit root

Exogenous: Constant

Lag Length: 0 (Automatic - based on SIC, maxlag=5)

\begin{tabular}{lccc}
\hline \hline & t-Statistic & Prob. $^{*}$ \\
\hline \hline Augmented Dickey-Fuller test statistic & -1.949016 & 0.3056 \\
\hline Test critical values: & 1\% level & -3.752946 & \\
& 5\% level & -2.998064 & \\
& 10\% level & -2.638752 & \\
\hline \hline
\end{tabular}

*MacKinnon (1996) one-sided p-values.

Augmented Dickey-Fuller Test Equation

Dependent Variable: D(LOGDRGDP)

Method: Least Squares

Date: 07/31/18 Time: 10:01

Sample (adjusted): 19932015

Included observations: 23 after adjustments

\begin{tabular}{lllll}
\hline \hline Variable & Coefficient & Std. Error & t-Statistic & Prob. \\
\hline \hline LOGDRGDP (-1) & -0.286348 & 0.146919 & -1.949016 & 0.0648 \\
C & 2.119815 & 1.069174 & 1.982666 & 0.0606 \\
\hline \hline R-squared & 0.153180 & Mean dependent var & 0.064842 \\
Adjusted R-squared & 0.112855 & S.D. dependent var & 0.902959 \\
S.E. of regression & 0.850483 & Akaike info criterion & 2.596916 \\
Sum squared resid & 15.18974 & Schwarz criterion & 2.695655 \\
Log likelihood & -27.86453 & Hannan-Quinn criter. & 2.621748 \\
F-statistic & 3.798662 & Durbin-Watson stat & 2.214683 \\
Prob(F-statistic) & 0.064777 & & \\
\hline \hline
\end{tabular}

\section{LNDRGDP Unit Root Test Result at First Difference}

Null Hypothesis: D(LOGDRGDP) has a unit root

Exogenous: Constant

Lag Length: 0 (Automatic - based on SIC, maxlag=5)

\begin{tabular}{lccc}
\hline \hline & t-Statistic & Prob. $^{*}$ \\
\hline \hline Augmented Dickey-Fuller test statistic & -5.908384 & 0.0001 \\
\hline Test critical values: & 1\% level & -3.769597 & \\
& 5\% level & -3.004861 & \\
& 10\% level & -2.642242 & \\
\hline \hline
\end{tabular}

*MacKinnon (1996) one-sided p-values.

Augmented Dickey-Fuller Test Equation

Dependent Variable: D(LOGDRGDP,2)

Method: Least Squares

Date: 08/05/18 Time: 10:26

Sample (adjusted): 19942015 
Included observations: 22 after adjustments

\begin{tabular}{lllll}
\hline \hline Variable & Coefficient & Std. Error & t-Statistic & Prob. \\
\hline \hline D (LOGDRGDP (-1)) & -1.286779 & 0.217789 & $\begin{array}{l}-5.908384 \\
0.572605\end{array}$ & 0.0000 \\
C & 0.111166 & 0.194141 & 0.5733 \\
\hline \hline R-squared & 0.635761 & Mean dependent var & -0.019529 \\
Adjusted R-squared & 0.617549 & S.D. dependent var & 1.462863 \\
S.E. of regression & 0.904673 & Akaike info criterion & 2.724021 \\
Sum squared resid & 16.36866 & Schwarz criterion & 2.823207 \\
Log likelihood & -27.96424 & Hannan-Quinn criter. & 2.747387 \\
F-statistic & 34.90900 & Durbin-Watson stat & 1.920661 \\
Prob(F-statistic) & 0.000009 & & \\
\hline \hline
\end{tabular}

LNREC Unit Root Test Result at Level

Null Hypothesis: LOGREC has a unit root

Exogenous: Constant

Lag Length: 2 (Automatic - based on SIC, maxlag=5)

\begin{tabular}{lccc}
\hline \hline & & t-Statistic & Prob.* \\
\hline \hline Augmented Dickey-Fuller test statistic & 1.227719 & 0.9973 \\
\hline Test critical values: & 1\% level & -3.752946 & \\
& 5\% level & -2.998064 & \\
& 10\% level & -2.638752 & \\
\hline \hline
\end{tabular}

*MacKinnon (1996) one-sided p-values.

Augmented Dickey-Fuller Test Equation

Dependent Variable: D(LOGREC)

Method: Least Squares

Date: 07/31/18 Time: 10:04

Sample (adjusted): 19932015

Included observations: 23 after adjustments

\begin{tabular}{lllll}
\hline \hline Variable & Coefficient & Std. Error & t-Statistic & Prob. \\
\hline \hline LOGREC (-1) & 0.011363 & 0.009255 & 1.227719 & 0.2345 \\
D (LOGREC (-1)) & 0.639409 & 0.209136 & 3.057382 & 0.0065 \\
D (LOGREC (-2)) & -1.074996 & 0.362014 & -2.969491 & 0.0079 \\
C & -0.028041 & 0.024769 & -1.132111 & 0.2717 \\
\hline \hline R-squared & 0.389194 & Mean dependent var & 0.001799 \\
Adjusted R-squared & 0.292751 & S.D. dependent var & 0.000567 \\
S.E. of regression & 0.000477 & Akaike info criterion & -12.30128 \\
Sum squared resid & $4.32 E-06$ & Schwarz criterion & -12.10380 \\
Log likelihood & 145.4647 & Hannan-Quinn criter. & -12.25161 \\
F-statistic & 4.035480 & Durbin-Watson stat & 2.198280 \\
Prob(F-statistic) & 0.022315 & & \\
\hline \hline
\end{tabular}

LNREC Unit Root Test Result at First Difference 
Null Hypothesis: D(LOGREC) has a unit root

Exogenous: Constant

Lag Length: 1 (Automatic - based on SIC, maxlag=5)

\begin{tabular}{llll}
\hline \hline & & t-Statistic & Prob.* $^{*}$ \\
\hline \hline Augmented Dickey-Fuller test statistic & -4.464511 & 0.0020 \\
\hline Test critical values: & 1\% level & -3.752946 & \\
& 5\% level & -2.998064 & \\
& 10\% level & -2.638752 & \\
\hline \hline
\end{tabular}

*MacKinnon (1996) one-sided p-values.

Augmented Dickey-Fuller Test Equation

Dependent Variable: D(LOGREC,2)

Method: Least Squares

Date: 07/31/18 Time: 10:09

Sample (adjusted): 19932015

Included observations: 23 after adjustments

\begin{tabular}{lllll}
\hline \hline Variable & Coefficient & Std. Error & t-Statistic & Prob. \\
\hline \hline D (LOGREC (-1)) & -1.273721 & 0.285299 & -4.464511 & 0.0002 \\
D (LOGREC (-1),2) & 0.846448 & 0.314396 & 2.692301 & 0.0140 \\
C & 0.002361 & 0.000543 & 4.351472 & 0.0003 \\
\hline \hline R-squared & 0.516102 & Mean dependent var & $1.36 \mathrm{E}-06$ \\
Adjusted R-squared & 0.467713 & S.D. dependent var & 0.000662 \\
S.E. of regression & 0.000483 & Akaike info criterion & -12.31189 \\
Sum squared resid & $4.67 \mathrm{E}-06$ & Schwarz criterion & -12.16378 \\
Log likelihood & 144.5867 & Hannan-Quinn criter. & -12.27464 \\
F-statistic & 10.66553 & Durbin-Watson stat & 1.900869 \\
Prob(F-statistic) & 0.000704 & & \\
\hline \hline
\end{tabular}

\section{LNREC Unit Root Test Result at Second Difference}

Null Hypothesis: D(LOGREC,2) has a unit root

Exogenous: Constant

Lag Length: 3 (Automatic - based on SIC, maxlag=6)

\begin{tabular}{llll}
\hline \hline & & t-Statistic & Prob.* \\
\hline \hline Augmented Dickey-Fuller test statistic & -2.245140 & 0.1975 \\
\hline Test critical values: & 1\% level & -3.788030 & \\
& 5\% level & -3.012363 & \\
& 10\% level & -2.646119 & \\
\hline \hline
\end{tabular}

*MacKinnon (1996) one-sided p-values.

Augmented Dickey-Fuller Test Equation

Dependent Variable: D(LOGREC,3)

Method: Least Squares

Date: 08/05/18 Time: 10:52

Sample (adjusted): 19962016

Included observations: 21 after adjustments 


\begin{tabular}{lllll}
\hline Variable & Coefficient & Std. Error & t-Statistic & Prob. \\
\hline \hline D (LOGREC (-1),2) & -5.680511 & 2.530137 & -2.245140 & 0.0392 \\
D (LOGREC (-1),3) & 4.330199 & 2.416667 & 1.791807 & 0.0921 \\
D (LOGREC (-2),3) & 3.763999 & 2.420763 & 1.554881 & 0.1395 \\
D (LOGREC (-3),3) & 3.305585 & 1.772017 & 1.865437 & 0.0806 \\
C & 0.001254 & 0.002397 & 0.523216 & 0.6080 \\
\hline \hline R-squared & 0.818292 & Mean dependent var & -0.000988 \\
Adjusted R-squared & 0.772865 & S.D. dependent var & 0.018323 \\
S.E. of regression & 0.008732 & Akaike info criterion & -6.439329 \\
Sum squared resid & 0.001220 & Schwarz criterion & -6.190633 \\
Log likelihood & 72.61295 & Hannan-Quinn criter. & -6.385355 \\
F-statistic & 18.01338 & Durbin-Watson stat & 1.954562 \\
Prob(F-statistic) & 0.000009 & & \\
\hline \hline
\end{tabular}

